ARTIKEL

\title{
Evaluasi Situs Web Covid19.Kaltimprov.go.id \\ Sebagai Penyebaran Informasi Pandemi Covid-19 Di Provinsi Kalimantan Timur
}

\section{Evaluation Of Covid19.Kaltimprov.go.id Website As Covid-19 Pandemic Information Spread in East Kalimantan province}

\section{OPEN ACCESS}

Citation: Irawan, B., \& Nizar Hidayat, M. (2021). Evaluasi Website Covid19. Kaltimprov.go.id Sebagai Kanal Resmi Penyebaran Informasi Pandemi Covid-19 Di Provinsi Kalimantan Timur. Matra Pembaruan. 5(2), 103-114

Received: February 22, 2021

Accepted: October 21, 2021

Published: November 29, 2021

Kata Kunci: Covid-19,

Situs web Pemerintah,

Evaluasi, Kalimantan Timur

Keywords: Covid-19,

Government Website,

Evaluation, Kalimantan

Timur

\author{
Bambang Irawan (iD 1, Muhammad Nizar Hidayat iD 2* \\ ${ }^{1}$ Program Studi Administrasi Publik Fakultas Ilmu Sosial dan Ilmu Politik Universitas Mulawarman \\ 2Program Studi Ilmu Komunikasi Fakultas Ilmu Sosial dan Ilmu Politik Universitas Lambung Mangkurat \\ ${ }^{1}$ Jl. Kuaro, Gn. Kelua, Kec. Samarinda Ulu, Kota Samarinda, Kalimantan Timur 75119, ${ }^{2}$ Jl. Brigjen H. \\ Hasan Basry, Kayu Tangi, Kec. Banjarmasin Utara, Kota Banjarmasin, Kalimantan Selatan 70123 \\ $\checkmark$ m.nizar.hidayat@gmail.com
}

\begin{abstract}
Abstrak: Pandemi global Covid-19 memberikan dampak kehidupan manusia, mulai dari dampak sosial sampai dengan tata laksana pemerintahan. Selain berkutat pada pengendalian penyebaran penyakit, pemerintah di seluruh dunia juga menghadapi ancaman lain yakni penyebaran informasi palsu terkait Covid-19. Distorsi informasi ini pada gilirannya justru menghambat upaya pemerintah dalam menangani dampak pandemi dan menambah masalah baru. Untuk itu penyampaian informasi yang benar dan tepat sasaran menjadi penting dalam upaya penanganan pandemi. Pada titik ini, peran e-government dituntut lebih dari sekadar memindahkan proses bisnis pemerintah dari luring ke daring. Evaluasi dari situs web resmi pemerintah ditujukan untuk menilai apakah situs web tersebut mampu mendukung tujuantujuan pemerintahan serta mendukung terwujudnya Good Governance. Penelitian ini akan mengevaluasi situs web resmi pemerintah yang memberikan informasi resmi terkait pandemi di Provinsi Kalimantan Timur melalui laman covid19.kaltimprov.go.id. Evaluasi ini menggunakan software bernama SortSite 5.3.5 yang akan berfungsi sebagai alat penguji otomatis berbasis daring. Adapun hal-hal yang diuji adalah errors, accessibility, compatibility dan standards yang juga disebut sebagai variabel pengukuran evaluasi situs web berdasarkan panduan W3C (World Wide Web Consortium). Berdasarkan hasil evaluasi yang didapatkan dari aplikasi SortSite 5.3.5 didapatkan data bahwa masalah terbanyak pada situs web covid19.kaltimprov.go.id berada pada variabel Accessibility dengan 85\%, kemudian variabel compatibility dan standards dengan rata-rata $72 \%$ dan yang terakhir adalah variabel errors dengan rata-rata permasalahan sebesar 71\% atau lebih tinggi daripada standar yang ditetapkan oleh W3C. Tentu saja hal ini merupakan temuan yang mengkhawatirkan dikarenakan banyaknya permasalahan secara teknis yang terdapat dalam situs web covid19.kaltimprov.go.id, yang pada gilirannya dapat mengakibatkan terhambatnya penyebaran informasi yang benar dan resmi terkait Covid-19.
\end{abstract}

\begin{abstract}
Global pandemic has affected all sectors of human life.. Aside from struggling to contain the spread of the disease, one of the biggest challenges of any government around the world is to prevent the dissemination of fake information regarding covid-19. Fake information not only dangerous for the people because they can cause psychological issues, but the most important thing is they can nullify government's strategic policy of covid containment. For that reason, dissemination of accurate and official information for all citizens is vital. In order to do so, the government has to maximize the instrument of communication channel, and one primary example is government website. The official website has to meet several criteria for carrying the tasks, and for that it is important to evaluate them. In this occasion we will evaluate the official website of covid19. kaltimprov.go.id as the primary source of any information related to the pandemic in Kalimantan Timur. We are using SortSite 5.3.5 software, an online-based website evaluating tools. The software will evaluate four variables, they are: errors, accessibility, compatibility and standards. Based on the result, we find that in covid19. kaltimprov.go.id, the problem is centered on the accessibility with $85 \%$ of issues followed by compatibility and standards with $72 \%$ while the last variable, errors, scored $71 \%$. This result gives the signal that there is something wrong with the website because the number of problems or issues on each variable is more than $50 \%$, and it could impact the success of government program in tackling fake information.
\end{abstract}




\section{Pendahuluan}

Pada akhir tahun 2019, dunia dikejutkan dengan merebaknya virus baru yang tergolong ke dalam kelompok coronaviridae atau yang sekarang populer dengan nama Covid-19 di China. Tercatat pada 23 April 2020 kurang lebih 3 juta kasus Covid-19 dan 200.000 kasus kematian yang terkait dengan Covid-19 terjadi secara global (V. J. Lee, Chiew, \& Khong, 2020).

Pandemi Covid-19 ini merupakan pandemi pertama di era digital dengan segala kecanggihan teknologi informasi (information and communication technology/ ICT) yang dikuasai manusia. Dalam Konferensi Munich pada 15 Februari 2020, Direktur Jenderal WHO sempat mengatakan bahwa "we're not just fighting an epidemic, we're fighting an infodemic". Infodemi merupakan istilah yang digunakan untuk menyinggung masifnya penyebaran informasi yang salah terkait dengan Covid-19. Informasi palsu (fake news) lebih cepat menyebar daripada virus Covid-19 itu sendiri. Distorsi informasi ini pada gilirannya justru menghambat penanganan Covid-19 yang efektif serta menimbulkan dampak negatif lainnya seperti menambah kecemasan, depresi psikis bahkan sampai pada teori konspirasi yang menafikan bahaya Covid-19 (Aminah, Sipahutar, Hs, Apriani, \& Maemunah, 2021).

Untuk itu penyampaian informasi yang benar dan tepat sasaran menjadi penting dalam upaya penanganan pandemi ini. Pemerintah melalui kanal-kanal komunikasi digitalnya menjadi ujung tombak yang diharapkan mampu menganulir disinformasi tersebut. Pada titik ini, peran e-government dituntut lebih dari sekadar memindahkan proses bisnis pemerintah yang dulunya luring menjadi daring.

E-government membawa harapan besar bagi terwujudnya penyelenggaraan Good Governance dengan hipotesis yang menunjukkan bahwa tingginya penguasaan dan penggunaan ICT dalam penyelenggaraan urusan pemerintahan selaras dengan meningkatnya kualitas pelayanan publik, terutama harapan bagi terbukanya aksesibilitas dan transparansi yang selama ini menjadi catatan bagi negara-negara berkembang termasuk Indonesia (Hermansyah, Jumroh, \& Djuyandi, 2019). Selain itu penggunaan ICT dalam penyelenggaraan urusan publik juga dipandang sebagai solusi bagi permasalahan klasik yang kerap dihadapi oleh negara karena teknologi mampu menjadi instrumen sekaligus rujukan yang valid dan reliable bagi masyarakat (Djuyandi, Herdiansah, Yulita, \& Sudirman, 2019). Pentingnya penggunaan ICT dalam penyelenggaraan urusan publik juga didorong oleh masifnya penggunaan serta pengaruh ICT oleh dan bagi masyarakat Indonesia dalam relasi sosial-politik mereka hal ini misalnya terkait dengan digital activism dan perilaku politik (political behavior) (Jesica, Sumadinata, \& Paskarina, 2020; Paskarina, 2020).

Beberapa contoh implementasi penggunaan ICT dalam penyelenggaraan urusan pemerintahan bisa dilihat dari studi-studi yang dilakukan terdahulu. Misalnya contoh kasus Pemerintah Provinsi Jawa Tengah yang mengembangkan aplikasi bebasis digital untuk mendukung program digitalisasi pemerintahan sebagai wujud dari pelaksanaan reformasi birokrasi. Pemerintah Provinsi Jawa Tengah mengembangkan sistem yang dinamakan Government Resources Management System atau GRMS yang merupakan suatu aplikasi yang mengintegrasikan proses pelayanan publik dan pembangunan daerah. Sistem itu kemudian memungkinkan masykarakat untuk mengawasi proses bisnis internal birokrasi Pemerintah Provinsi Jawa Tengah dan dengan demikian akan tercipta open government yang dicirikan dengan transparansi, akuntabilitas yang tinggi serta profesionalisme dari para aparatur birokrasi (Sofianto, 2019).

Contoh selanjutnya adalah penggunaan medium video tutorial berbasis digital yang bertujuan untuk memudahkan pengajuan izin bagi pengguna atau masyarakat di Kota Samarinda. Dalam studi yang dilakukan, ditemukan data bahwa salah satu kendala yang dihadapi oleh masyarakat Kota Samarinda untuk memaksimalkan digitalisasi pengajuan atau permohonan izin adalah rendahnya kemampuan masyarakat dalam penggunaan media digital terlebih internet (digital literacy). Untuk itu Pemerintah Kota Samarinda melalui Dinas Penanaman Modal dan Pelayanan Terpadu Satu Pintu (DPMPTSP) mencoba untuk membuat satu inovasi dengan menggunakan ICT yakni berupa penyematan video tutorial pada situs web portal permohonan izin. Video 
tutorial itu dilengkapi dengan panduan audio visual serta teks yang akan memandu masyarakat dalam tahapan pengajuan izin secara daring (Irawan, Hidayat, Akbar, \& Khanz, 2020).

Afirmasi dari korelasi positif antara penggunaan ICT dan kemudahan pelayanan publik dan good governance ini juga datang dari penelitian Ikhsani dan Rifki (2017) yang mendokumentasikan bagaimana penggunaan ICT pada poses pengurusan Izin Mendirikan Bangunan atau IMB di Kota Pontianak. Dengan penerapan sistem registrasi daring. setidaknya terdapat tiga keuntungan yang didapat oleh masyarakat Kota Pontianak yakni terkait aspek efisiensi waktu, biaya dan aksesibilitas yang mudah terhadap pelayanan IMB.

Tidak hanya mempermudah urusan pelayanan publik secara spesifik, namun penggunaan ICT dalam urusan pemerintahan juga berdampak besar dalam memudahkan urusan internal pemerintahan. Sebagaimana yang ditunjukkan dalam inovasi manajemen retibusi pasar di Kota Surakarta (Ratna Sari, 2019). Dengan dimanfaatkannya "Teknologi Aplikasi e-Retribusi Pasar" atau disingkat "Tape Pasar" di Kota Surakarta maka Pemerintah daerah bisa lebih mudah untuk mengelola retribusi pasar dengan tingkat akuntabilitas, transparansi dan profesionalisme yang tinggi sehingga celah-celah penyimpangan dalam retribusi pasar bisa dihindari bahkan ditiadakan.

Studi-studi terdahulu sebagaimana yang disampaikan dan ditunjukkan pada beberapa daerah di Indonesia tadi bisa menjadi pijakan untuk membangun argumentasi bahwa penggunaan ICT dalam urusan pemerintahan sangat berdampak positif. Korelasi positif antara penggunaan ICT dalam urusan penyelenggaraan urusan pemerintah dan kualitas pelayanan publik, tata kelola pemerintahan, transparansi akuntabilitas dan lain sebagainya tidak terlepas dari kemudahan dan efisiensi yang ditawarkan oleh ICT.

Salah satu fitur penting dari ICT yang berperan penting dalam membantu penyelenggaraan urusan pemerintah pada abad 21 ini adalah Situs web atau situs. Situs web pada dasarnya merupakan halaman atau laman yang isinya adalah informasi layaknya media lain namun perbedaannya terletak pada penyajian informasi pada Situs web yang berbasis daring atau melalui jaringan internet. Informasi di dalam suatu Situs web dikenal dengan istilah konten. Konten ini pada gilirannya dapat berupa informasi tertulis (teks), visual (gambar statis dan dinamis), audio dan beragam jenis informasi lainnya.

Sebagaimana yang telah disinggung sebelumnya, kekuatan mendasar yang dimiliki oleh ICT dan dalam hal ini situs web adalah aksesibilitas yang tinggi, daya jangkau yang luas dan efisiensi biaya serta waktu. Informasi yang dimuat dalam situs web akan memiliki jangkauan yang luas, aksesibilitas yang tinggi karena biaya yang murah dan bisa diakses dimanapun kapanpun (dengan catatan memiliki jaringan internet). Tentu saja pada gilirannya penggunaan situs web dalam penyelenggaraan urusan pemerintahan akan berdampak positif. Informasi publik yang selama ini disampaikan melalui koran, radio, televisi dan media lain bisa dimuat di dalam suatu situs web resmi milik pemerintah yang bisa diakses dengan cepat, murah dan di mana saja. Penggunaan serta pengoptimalan situs web resmi pemerintah sebagai sarana diseminasi informasi publik dan media interaksi kepada masyarakat merupakan wujud nyata dari penerapan e-government yang mendorong terciptanya tata kelola pemerintahan yang baik atau Good Governance.

Dengan semakin pentingnya situs web pemerintah sebagai salah satu instrumen penting e-government, maka kajian mengenai situs web pun banyak dilakukan oleh para penstudi sebelumnya. Satu sub-kajian penting dalam studi tentang situs web adalah kajian mengenai evaluasi situs web. Evaluasi dari situs web resmi pemerintah ditujukan untuk menilai apakah situs web tersebut mampu mendukung tujuan-tujuan dari suatu pemerintahan tersebut serta apakah situs web tersebut bisa mendukung terwujudnya Good Governance (Cahyono \& Susanto, 2019; Effendi \& Susanto, 2019; Elling, Lentz, de Jong, \& van den Bergh, 2012; Khalid \& Lavilles, 2019; Prahono \& Elidjen, 2015, 2017). 
Tabel 1. Variabel Evaluasi Situs web Berdasarkan SortSite 5.3.5

Untuk itu banyak sekali kajian evaluasi situs web yang terdapat dalam literatur seperti kajian model evaluasi situs web (Holzer \& Manoharan, 2016; Karkin \& Janssen, 2014), identifikasi tahapan atau kedewasaan e-government dari suatu pemerintah (Layne \& Lee, 2001; Moon, 2002), keterkaitannya dengan upaya untuk mendukung penerapan prinsip-prinsip demokrasi (Karkin \& Janssen, 2014; Lee-Geiller \& Lee, 2019) dan lain sebagainya.

Berdasarkan hal tersebut maka penulis mencoba untuk melanjutkan agenda akademik dalam kajian evaluasi situs web pemerintah dengan menaruh fokus pada evaluasi situs web pemerintah Provinsi Kalimantan Timur (Irawan \& Hidayat, 2019). Perbedaanya ada pada fokus penelitian kali ini yang bertujuan pada evaluasi situs web covid19.kaltimprov.go.id/ sebagai kanal yang khusus dibentuk guna penyampaian informasi resmi terkait pandemi Covid-19 di Provinsi Kalimantan Timur.

Evaluasi situs web sebenarnya merupakan satu dari serangkaian agenda penelitian jangka panjang yang ditujukan untuk mempelajari e-government di Indonesia pada umumnya dan di Provinsi Kalimantan Timur pada khususnya. Terlebih lagi pada masa pandemi Covid-19, di mana studi menunjukkan bahwa komunikasi daring antara pemerintah dan masyarakat melalui kanal situs web, sosial media dan lain sebagainya menjadi semakin penting (T. D. Lee, Lee-Geiller, \& Lee, 2021). Selain itu, Provinsi Kalimantan Timur dipilih karena merupakan salah satu daerah yang menjadi episentrum Covid-19 di Indonesia, sehingga keberadaan situs web sebagai medium komunikasi daring sangat diperlukan untuk mereduksi dampak negatif dari wabah ini (CNBC Indonesia, 2021).

\section{Metode}

Penelitian ini adalah penelitian deskriptif kualitiatif. Data dikumpulkan melalui observasi objek penelitian, dalam konteks ini adalah situs web covid19. kaltimprov.go.id. Fokus penelitian kali ini bisa diihat dari variabel evaluasi situs web yang digunakan. Variabel yang dinilai adalah Errors, Accessibility, Compatibility, dan Standards. Adapun variabel evaluasi tersebut diperoleh dari perangkat lunak (software) SortSite 5.3.5 sebagai alat uji situs web yang berbasis daring.

Variabel Evaluasi Situs Web

$\begin{array}{ll}\text { Errors } & \text { Percentage of Broken Links (Persentase tautan yang rusak) } \\ \text { Accessibility } & \begin{array}{l}\text { Percentage of Accessibility Issues -in line with WCAG 2.0 } \\ \text { Guidelines (Persentase masalah Aksesibilitas yang selaras dengan } \\ \text { panduan WCAG 2.0) }\end{array} \\ \text { Compatibility } & \begin{array}{l}\text { Percentage of Compatibility Issues (Persentase masalah } \\ \text { Kompatibilitas) }\end{array} \\ \text { Standards } & \begin{array}{l}\text { Percentage of pages that do not comply with W3C standards } \\ \text { (Persentase halaman yang tidak memenuhi standar W3C) }\end{array}\end{array}$

Sumber: (SortSite 5.3.5, 2020)

Metode evaluasi yang dilakukan secara otomatis dengan bantuan SortSite 5.3.5. Software ini merupakan alat evaluasi situs web otomatis. Alat ukur serta kriteria yang ditetapkan dalam SortSite 5.3.5 mengacu pada WCAG (Web Content Accessibility Guidelines) yang ditetapkan oleh World Wide Web Consortium (W3C) sebagai konsensus dunia (Fithriyaningrum, Kusumawardhani, \& Wibirama, 2021). Penyeragaman konten situs web dinilai perlu untuk dilakukan agar aksesibilitas situs web bisa menjangkau semua orang termasuk orang dengan disabilitas dan kondisi tertentu.

Meski terdapat banyak software evaluasi situs web lain, namun SortSite 5.3.5 dinilai lebih unggul karena lebih rinci dalam mengadopsi kriteria evaluasi situs web WCAG (Tollefsen \& Ausland, 2018). Keunggulan ini membuat SortSite banyak digunakan untuk menilai apakah suatu situs web sudah memenuhi kriteria yang ditetapkan oleh WCAG (Alismail \& Chipidza, 2021; Kondoro \& Mtebe, 2017; Reis et al., 2017; Yerlikaya \& Durdu, 2017) 
Gambar 1. Tampilan Halaman Muka covid19.kaltimprov.go.id

Tabel 2. Hasil Evaluasi Situs web covid19.kaltimprov.go.id

Untuk menggunakan SortSite 5.3.5 dimulai dengan menginput alamat situs web covid19. kaltimprov.go.id ke dalam kolom evaluasi yang disediakan di dalam perangkat. Kemudian SortSite 5.3.5 akan mengevaluasi empat variabel yang disebutkan sebelumnya (Errors, Accessibility, Compatibility, dan Standards). Setelah selesai, hasil dari evaluasi akan ditampilkan berikut dengan jumlah keseluruhan halaman situs web yang dipindai, persentase masalah yang terdapat pada masing-masing variabel serta benchmarking atau perbandingan dengan rata-rata hasil evaluasi pada situs web lainnya. Batas relatif dari issue atau permasalahan pada masing-masing variabel adalah antara 15 sampai dengan 20 persen. Artinya jika SortSite menemukan permasalahan lebih dari batas tersebut maka situs web dinilai kurang atau tidak memenuhi kriteria yang ditetapkan oleh WCAG.

\section{Hasil Dan Pembahasan}

Berdasarkan hasil evaluasi yang dilakukan dengan bantuan SortSite 5.3.5, didapatkan data bahwa masalah terbanyak pada website covid19.kaltimprov.go.id berada pada variabel accessibility dengan 85\%, kemudian variabel compatibility dan standards dengan rata-rata $72 \%$ dan yang terakhir adalah variabel errors dengan rata-rata permasalahan sebesar 71\%. Tentu saja hal ini merupakan temuan yang mengkhawatirkan dikarenakan banyaknya permasalahan secara teknis seperti kompatibilitas dengan beberapa browser serta tampilan visual yang tidak proporsional dan kendala lain yang terdapat dalam situs web covid19.kaltimprov.go.id.

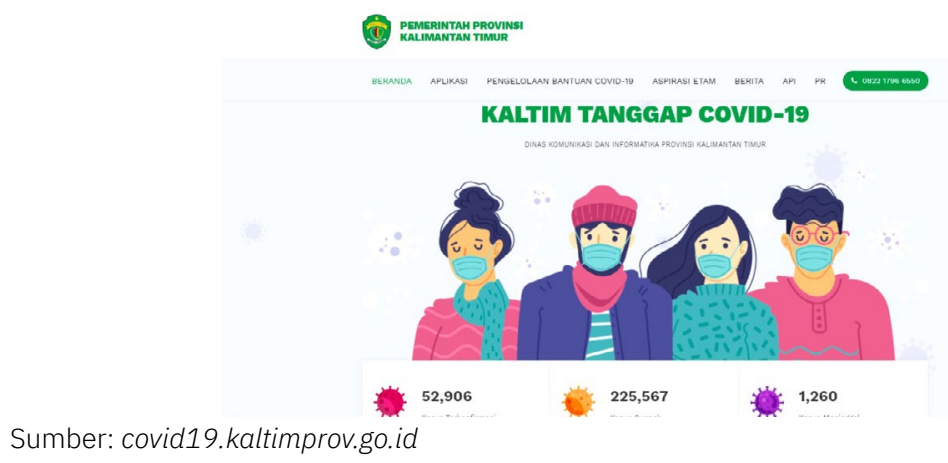

Melihat hasil summary SortSite 5.3.5, ditemukan data bahwa semua variabel yang dievaluasi dalam situs covid19. kaltimprov.go.id memiliki nilai diatas 50\% dan termasuk dalam kategori worse than average atau lebih buruk dari rata-rata. Perbandingan atau benchmarking yang dilakukan oleh SortSite ini merupakan fitur otomatis yang disediakan dengan menggunakan metadata perbandingan dari ribuan situs web di seluruh dunia sesuai dengan kriteria ideal yang telah ditentukan.

Variabel Evaluasi Situs Web

\begin{tabular}{ll} 
Errors & $71 \%$ (lebih buruk daripada hasil rata-rata) \\
\hline Accessibility & $85 \%$ (lebih buruk daripada hasil rata-rata) \\
\hline Compatibility & $72 \%$ (lebih buruk daripada hasil rata-rata) \\
\hline Standards & $72 \%$ (lebih buruk daripada hasil rata-rata) \\
\hline Kualitas Keseluruhan & $86 \%$ Halaman Bermasalah
\end{tabular}

Sumber: (SortSite 5.3.5, 2020)

\section{III.1. Errors}

Dalam keterangan hasil evaluasi pada variabel errors yang dilakukan perangkat SortSite 5.3.5 terhadap situs covid19.kaltimprov.go.id, telaah fitur errors yang bermasalah hanya terdapat pada fitur tautan yang tidak terbuka atau tidak bisa diakses (broken links). Sedangkan fitur lainnya relatif tidak ada masalah yang ditemukan sepeti server configuration, ASP, ASP.NET and PHP Script Errors, dan Internet RFCs dimana hasil evaluasi menunjukkan keterangan no issues found. 
Tabel 3 . Tabulasi Masalah dalam Variabel Errors
Secara keseluruhan terdapat enam issues atau permasalahan utama yang terdapat pada variabel errors di situs covid19.kaltimprov.go.id. Adapun rangkuman keenam permasalahan tersebut bisa dilihat pada tabel dibawah ini:

\begin{tabular}{|c|c|c|c|}
\hline No & Permasalahan & Keterangan & $\begin{array}{l}\text { Jumlah } \\
\text { Halaman }\end{array}$ \\
\hline 1 & $\begin{array}{l}\text { Tautan ini rusak. Target tautan } \\
\text { tidak dapat dimuat karena } \\
\text { kesalahan HTTP. }\end{array}$ & $\begin{array}{l}\text { Ini terkadang merupakan masalah sementara, } \\
\text { tetapi jika terus berlanjut, ini menunjukkan } \\
\text { masalah serius pada server web Anda. }\end{array}$ & 2 \\
\hline 2 & $\begin{array}{l}\text { Tautan ini rusak. Nama server } \\
\text { web target tidak ditemukan di } \\
\text { DNS }\end{array}$ & $\begin{array}{l}\text { Ini sering terjadi ketika situs tujuan tidak lagi } \\
\text { beroperasi, atau www. telah dihilangkan dari } \\
\text { depan nama domain. Ini juga bisa menjadi } \\
\text { masalah sementara jika server cache DNS lokal } \\
\text { tidak tersedia untuk sementara. }\end{array}$ & 6 \\
\hline
\end{tabular}

\begin{tabular}{|c|c|c|c|}
\hline 3 & $\begin{array}{l}\text { Tautan ini rusak. Halaman tidak } \\
\text { dapat ditemukan di server web } \\
\text { target }\end{array}$ & $\begin{array}{l}\text { Memperbaiki ini tergantung pada bagaimana } \\
\text { tautan menjadi rusak: } \\
\text { - Tautan salah ketik dan harus diperbaiki } \\
\text { - Halaman tujuan telah dipindahkan dan } \\
\text { tautannya harus diperbarui } \\
\text { - Halaman tujuan tidak ada lagi dan link harus } \\
\text { dihapus } \\
\text { - Sebuah file telah terhapus secara tidak sengaja } \\
\text { dan harus diganti }\end{array}$ & 19 \\
\hline 4 & $\begin{array}{l}\text { Tautan ini rusak. src atau href } \\
\text { adalah string kosong. }\end{array}$ & $\begin{array}{l}\text { href=" atau src=" dapat menyebabkan efek tak } \\
\text { terduga seperti lonjakan lalu lintas atau kerusakan } \\
\text { cookie, dan menyebabkan peristiwa kesalahan } \\
\text { JavaScript diaktifkan di Firefox }\end{array}$ & 8 \\
\hline 5 & $\begin{array}{l}\text { Tautan ini rusak. Server web } \\
\text { target tidak dapat dijangkau } \\
\text { atau tidak lagi berjalan di URL } \\
\text { ini. }\end{array}$ & $\begin{array}{l}\text { Ini bisa menjadi masalah sementara, tetapi juga } \\
\text { terjadi jika situs tujuan tidak lagi beroperasi atau } \\
\text { berada di belakang firewall. Sebagian besar server } \\
\text { pementasan dan pengembangan dilindungi oleh } \\
\text { firewall. Jika situs masih beroperasi, laporkan } \\
\text { masalah ini ke Departemen TI atau ISP Anda. }\end{array}$ & 1 \\
\hline 6 & $\begin{array}{l}\text { Halaman ini mengandung } \\
\text { beberapa kesalahan ejaan }\end{array}$ & $\begin{array}{l}\text { Klik kata untuk menambahkannya ke kamus. Klik } \\
\text { lagi jika Anda ingin menghapusnya }\end{array}$ & 886 \\
\hline
\end{tabular}

Sumber: (SortSite 5.3.5, 2020)

Secara keseluruhan, variabel errors memiliki 71\% permasalahan yang diukur berdasarkan kriteria yang telah ditetapkan sebelumnya. Meski hasil evaluasi menunjukkan angka 71\% yang merupakan persentase buruk serta termasuk dalam kriteria "worse than average" sesuai dengan benchmarking atau pemeringkatan otomatis yang dilakukan oleh SortSite 5.3.5., namun apabila ditelaah lebih dalam, sebagian besar permasalahan pada variabel ini "hanya" terdapat pada permasalahan spelling errors atau salah pengejaan pada 886 halaman. Ditambah lagi dengan default SortSite yang menggunakan bahasa Inggris, maka tidak mengherankan apabila permasalahan ini akan terus muncul dalam jumlah yang signifikan pada evaluasi terhadap situs web yang mengandung konten berbahasa non-Inggris. Sedangkan permasalahan utama dalam variabel errors (tautan yang tidak bisa diakses/terbuka) jauh lebih sedikit yakni 36 halaman.

Misalnya bisa dilihat pada gambar 3. Salah satu halaman dalam situs web yang memuat informasi umum atau halaman muka, tidak bisa terbuka dan hanya memuat tulisan "maintenance". Meski tidak terlalu banyak, namun hal ini tetap menjadi poin yang harus diperhatikan mengingat situs web ini bersifat resmi dan diharapkan menjadi rujukan bagi siapapun yang ingin mengetahui informasi terkait Covid-19 di Provinsi Kalimantan Timur. Terlebih lagi mengingat situs web ini didanai sepenuhnya oleh dana publik, maka sudah selayaknya hal-hal kecil seperti halaman yang tidak bisa diakses/ terbuka tidak ada dalam situs web resmi. 
Maintenance

Gambar 2. Contoh Halaman covid19.kalimprov.go.id yang Tidak Bisa Diakses/Terbuka

Tabel 4. Indikator Penilaian dalam Variabel Accessibility
Sumber: covid19.kaltimprov.go.id

\section{III.2. Accessibility}

Variabel accessibility menunjukan permasalahan keterjangkauan atau aksesibilitas terhadap situs. Permasalahan ini mengindikasikan adanya kendala bagi pengguna yang berusia lanjut (older users), orang-orang dengan disabilitas atau memiliki kebutuhan khusus terkait keterjangkauan. Meski demikian tes otomatis yang dilakukan mesin atau aplikasi/software tidak bisa menunjukkan semua kendala keterjangkauan secara komprehensif dan biasanya tes keterjangkauan ini dilakukan berbarengan dengan tes manual dengan mengujinya langsung kepada pengguna (users).

Dalam menguji aksesibilitas atau keterjangkauan suatu situs, SortSite 5.3.5 bekerja dengan berdasarkan peraturan federal Amerika Serikat yang bernama the Rehabilitation Act of 1973. Dalam section 508 pada peraturan tersebut, diwajibkan akses yang sama terhadap informasi bagi seluruh pegawai federal AS baik yang memiliki disabilitas maupun yang tidak. Persyaratan teknis tentang standar yang harus termuat dalam suatu situs diperbaharui pada Januari 2017 untuk menyelaraskan dengan panduan yang dikeluarkan oleh WCAG 2.0 atau Web Content Accessibility Guidelines 2.0.

\section{Level Keterangan}

A Halaman dengan masalah level A tidak dapat digunakan untuk beberapa orang

AA Halaman dengan masalah level AA sangat sulit digunakan

AAA Halaman dengan masalah level AAA bisa jadi sulit digunakan

Sumber: (SortSite 5.3.5, 2020)

WCAG 2.0 sendiri merupakan suatu panduan yang merangkum rekomendasi yang diharapkan bisa membuat konten-konten pada suatu situs lebih terjangkau oleh banyak orang/ panduan ini memang ditujukan untuk membuka akses seluas-luasnya terhadap isi konten situs bagi orang-orang dengan disabilitas seperti kebutaan dan pandangan yang terganggu/kabur, permasalahan pendengaran dan ketulian, kesulitan belajar, keterbatasan kognitif, keterbatasan gerakan, bisu, photosesivity serta kombinasi dari permasalahan diatas. Dengan mengikuti panduan WCAG 2.0 maka suatu situs akan bisa diakses informasinya oleh orang-orang dengan kriteria diatas (W3C, 2008).

Accessibility Guidelines (WCAG) adalah panduan yang menggariskan standar yang dibuat oleh World Wide Web Consortium (W3C) dibawah mandat Web Accesibility Initiative (WAI) sejak 1999. Mengacu pada standar yang ditetapkan dalam WCAG, website dituntut untuk memenuhi beberapa fitur dasar. Hal ini termasuk menyediakan alternatif teks bagi konten non-teks, penyediaan alternatif untuk media, berbagai cara presentasi konten, serta teks konten yang harus mudah dimengerti, predictable, dan kompatibel (Kesswani \& Kumar, 2016).

Berdasarkan indikator penilaian variabel accessibility yang digunakan pada perangkat SortSite 5.3.5, terdapat tiga tingkatan atau level penilaian yakni level A, AA, dan AAA. Level A merupakan level terparah yang mengindikasikan bahwa konten pada halaman situs web tidak bisa diakses oleh beberapa orang tertentu. Selanjutnya adalah level AA yang berarti bahwa informasi pada halaman situs web sangat sukar untuk dimengerti atau halaman sangat sulit untuk digunakan. Terakhir adalah level 
Gambar 3. Contoh Halaman covid19.kaltimprov.go.id yang tidak Bisa Diakses.
AAA yang merupakan tingkatan paling rendah yang mengindikasikan bahwa informasi pada halaman bisa jadi/berpotensi sulilt untuk dimengerti dan digunakan.

Variabel accessibility merupakan variabel dengan penilaian terendah dari keempat variabel yang dievaluasi pada situs web covid19.kaltimprov.go.id dengan permasalahan yang tedapat pada 1065 halaman situs atau 85\% dari keseluruhan halaman dan tergolong pada kategori worse than average berdasarkan pemeringkatan otomatis SortSite. Adapun rinciannya adalah: 26 jenis permasalahan tingkat A pada 1058 halaman, 2 jenis permasalahan tingkat AA pada 10 halaman, dan 4 jenis permasalahan tingkat AAA pada 899 halaman. Dari rincian tersebut bisa dilihat bahwa terdapat overlapping atau tumpang tindih permasalahan pada sebagian halaman atau dengan kata lain terdapat halaman yang memiliki lebih dari satu tingkat permasalahan.

Contohnya bisa dilihat pada gambar 4 dimana informasi terkait dengan data jumlah masyarakat yang terdampak covid-19 pada masing-masing kabupaten/kota di Kalimantan Timur tidak bisa diakses dengan sempurna dan hanya menampilkan teks berupa script. Hal ini tentu saja berpengaruh terhadap diseminasi informasi resmi terkait jumlah warga yang terdampak Covid-19 di Provinsi Kalimantan Timur terutama bagi masyarakat yang memiliki kondisi khusus seperti penglihatan yang kabur, usia lanjut dan lain sebagainya.

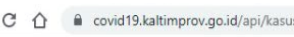

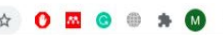

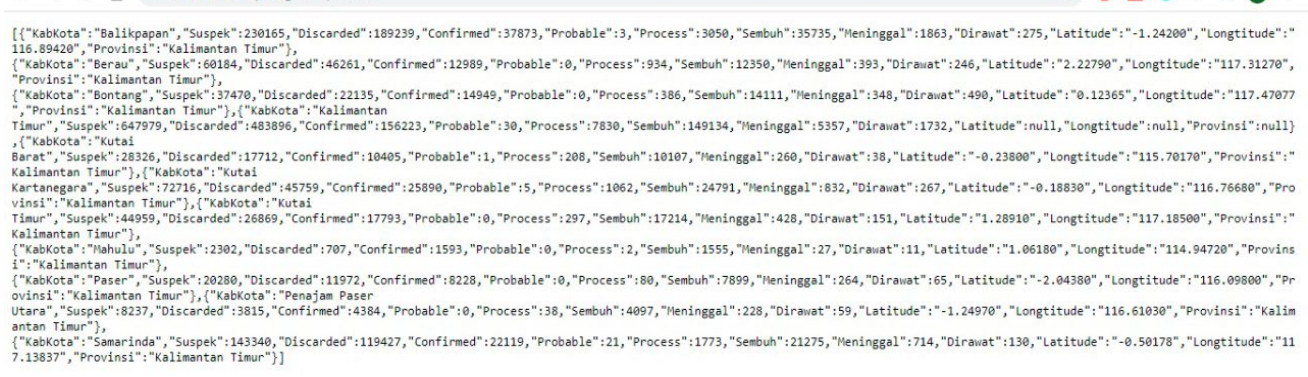

Sumber: covid19.kaltimprov.go.id

\section{III.3. Compatibility}

Variabel selanjutnya adalah Compatibility yang melihat performa situs web yang diakses melalui berbagai browser dan sistem operasi. Hal ini menjadi penting karena pada saat ini terdapat berbagai macam browser, dan yang lebih penting lagi bahwa masyarakat saat ini cenderung untuk mengakses internet melalui smartphone. Untuk itu suatu situs web resmi seperti covid19.kaltimprov.go.id dituntut untuk bisa diakses melalui berbagai browser dan tipe smartphone tersebut. Adapun browser compatibility yang diuji oleh SortSite 5.3.5 antara lain:
1. Android Browser Compatibility
2. Chrome Browser Compatibility
3. Edge Browser Compatibility
4. Internet Explorer Browser Compatibility (version 11)
5. Firefox Browser Compatibility
6. Opera Browser Compatibility
7. Safari Browser Compatibility
8. iPhone/iPad Browser Compatibility (version 9)

SortSite 5.3.5 akan menguji apakah situs covid19.kaltimprov.go.id kompatibel atau bisa diakses dengan baik oleh pengguna dari delapan browser atau alat penelusuran yang berbeda. Dari ke delapan browser tersebut hanya browser Blackberry yang tidak diuji oleh SortSite. Secara umum variabel compatibility mencatat terdapat 896 halaman dengan permasalahan compaltibility atau $72 \%$ dari total halaman situs yang juga masuk pada kategori worse than average. 
Tabel 5. Permasalahan Variabel Compatibility pada Situs Web covid19.kaltimprov.go.id

\begin{tabular}{|c|c|c|}
\hline Permasalahan & Keterangan & Jumlah Halaman \\
\hline \multirow{2}{*}{$\begin{array}{l}\text { Konten atau fungsionalitas tidak } \\
\text { ada }\end{array}$} & Gambar SVG tidak didukung oleh browser lama. & 887 \\
\hline & $\begin{array}{l}\text { NS telp: Skema URL tidak didukung oleh } \\
\text { beberapa browser desktop dan tablet }\end{array}$ & 811 \\
\hline \multirow{5}{*}{$\begin{array}{l}\text { Tata letak utama atau masalah } \\
\text { kinerja }\end{array}$} & $\begin{array}{l}\text { Properti kustom CSS tidak didukung oleh } \\
\text { beberapa browser. }\end{array}$ & 2 \\
\hline & $\begin{array}{l}\text { NS jalur klip: Properti CSS tidak didukung oleh } \\
\text { beberapa browser. }\end{array}$ & 1 \\
\hline & $\begin{array}{l}\text { CSS filter latar belakang: properti tidak didukung } \\
\text { oleh beberapa browser }\end{array}$ & 1 \\
\hline & $\begin{array}{l}\text { CSS Saring: properti tidak didukung oleh } \\
\text { beberapa browser. }\end{array}$ & 6 \\
\hline & $\begin{array}{l}\text { NStampilan: fleksibel Properti CSS tidak } \\
\text { berfungsi dengan benar di beberapa browser }\end{array}$ & 3 \\
\hline \multirow[t]{5}{*}{$\begin{array}{l}\text { Tata letak kecil atau masalah } \\
\text { kinerja }\end{array}$} & $\begin{array}{l}\text { Filter DirectX tidak didukung oleh IE10 atau yang } \\
\text { lebih baru. }\end{array}$ & 4 \\
\hline & $\begin{array}{l}\text { NS anak yatim: Properti CSS tidak didukung oleh } \\
\text { beberapa browser. }\end{array}$ & 3 \\
\hline & $\begin{array}{l}\text { NS page-break-setelah: Nilai properti CSS } \\
\text { dihindari, kiri dan kanan tidak didukung oleh } \\
\text { Firefox. }\end{array}$ & 3 \\
\hline & $\begin{array}{l}\text { NS posisi: lengket Properti CSS hanya didukung } \\
\text { oleh Firefox } 32 \text { dan Safari 6.1. }\end{array}$ & 2 \\
\hline & $\begin{array}{l}\text { NS janda: Properti CSS tidak diterapkan oleh } \\
\text { beberapa browser }\end{array}$ & 3 \\
\hline
\end{tabular}

Sumber: (SortSite 5.3.5, 2020)

Berdasarkan pengujian yang dilakukan oleh SortSite terhadap situs covid19. kaltimprov.go.id ditemukan bahwa browser yang paling kompatibel adalah Microsoft Edge, iOS, dan Android dengan status All Clear pada kriteria critical issues. Artinya situs web covid19.kaltimprov.go.id tidak akan banyak bermasalah ketika dibuka dengan menggunakan ketiga browser tersebut.

Lain halnya dengan browser yang lain yang mencatat adanya critical issues yang cukup signifikan. Sebagai catatan pada gawai android dengan versi 4.4 keatas browser yang digunakan sudah menggunakan Google Chrome sebagai browser default-nya. Selanjutnya pada kriteria major issues, hampir semua browser memiliki permasalahan pada kriteria ini kecuali pada browser Microsoft Edge. Dan yang terakhir adalah minor issues dimana hampir semua browser juga memiliki permasalahan ini kecuali pada browser IOS.

Bisa dikatakan bahwa situs web covid19.kaltimprov.go.id memiliki permasalahan serius terkait dengan variabel compatibility khususnya pada critical issues yang terdapat pada 887 halaman. Permasalahan terletak pada kurang kompatibelnya situs web covid19.kaltimprov.go.id dengan beberapa browser seperti Blackberry, Safari, Firefox dan lainnya. Kekurangan dalam variabel kompatibiltas ini akan mempengaruhi konten-konten situs web yang mungkin tidak bisa terakses dengan baik pada browserbrowser itu.

Tentu saja hal ini akan membuat penyampaian informasi yang terkandung dalam website ini kurang maksimal karena idealnya suatu situs web, lebih-lebih situs web yang bertujuan untuk pelayanan dan informasi publik harus bisa terbuka dan bekerja dengan baik dalam berbagai browser yang digunakan oleh masyarakat.

\section{III.4. Standards}

Variabel terakhir adalah Standards yang melihat kepatuhan halaman situs web dengan standar yang ditetapkan oleh W3C. Ada empat alat uji yang digunakan oleh SortSite 5.3.5 yakni: 
Tabel 6. Hasil Penilaian dalam Variabel Standards

\section{W3C CSS Validation}

2. W3C Deprecated Features

3. W3C HTML Validation

4. W3C HTML5

Hasil summary pengujian variabel standards pada situs web covid19. kaltimprov. go.id menunjukkan bahwa terdapat permasalahan pada alat uji W3C HTML/XHTML Validation dan W3C CSS Validation, dan hanya pada W3C Deprecated Features saja yang tidak memiliki permasalahan. Secara umum variabel standards mencatat 895 halaman yang memiliki permasalahan dengan kaidah-kaidah yang telah ditetapkan oleh W3C atau sekitar 72\% dari total halaman pada situs serta masuk pada kategori worse than average.

\begin{tabular}{lccc} 
& Prioritas & Jumlah Permasalahan & Jumlah Halaman \\
\hline 1 (Tinggi) & 34 & 2 \\
\hline 2 (Sedang) & 34 & 2 \\
3 (Rendah) & 34 & 2
\end{tabular}

Sumber: (SortSite 5.3.5, 2020)

Variabel standards ini menggunakan tiga ukuran permasalahan untuk menentukan performa suatu situs web. Pertama adalah prioritas 1 atau tinggi yang mengindikasikan kelalaian signifikan dalam mengikuti kaidah W3C, berikutnya adalah prioritas 2 atau sedang yang bermakna terdapat ketidaksesuaian standar pada beberapa halaman situs web dan terakhir prioritas 3 atau rendah yang berarti sebagian kecil halaman tidak mengikuti standar W3C.

Pada variabel standards ini ditemukan data bahwa permasalahan utama yang masuk dalam kategori prioritas 1 (tinggi) sangat mendominasi. Dengan jumlah permasalahan prioritas 1 sebesar 895 halaman maka matriks standards masuk dalam kategori worse than average.

Secara umum variabel standards mengatur tentang teknis tata kelola data dalam website yang tertuang dalam bentuk teks atau gambar dengan tujuan untuk memudahkan pengguna dalam mengakses konten yang ada di dalam situs web tersebut. Sebagai contoh pada pengukuran HTML misalnya, pengaturan data program di dalam situs web berdampak pada kompatibilitas dan aksesibilitas website. Sehingga apabila pengaturan HTML kurang tepat maka akan menimbulkan masalah pada kompatiibilitas dan aksesibilitas.

Terkait hasil evaluasi ini maka bisa disimpulkan bahwa mayoritas halaman pada situs covid19. kaltimprov.go.id belum memenuhi kriteria standar yang telah ditetapkan oleh W3C dalam membangun situs yang baik dan mudah dijangkau oleh masyarakat luas.

\section{Kesimpulan}

Penelitian ini bertujuan untuk menyelidiki performa situs web resmi Pemerintah Provinsi Kalimantan Timur yang khusus dibentuk untuk penyebaran informasi terkait penyebaran dan data-data penting tentang pandemi Covid-19 di Kaltim. situs web covid19.kaltimprov.go.id menjadi rujukan resmi yang diharapkan mampu menyebarluaskan informasi yang benar kepada masyarakat. Oleh sebab itu situs web ini perlu untuk bekerja dengan performa maksimal guna mendukung tujuan tersebut. Penelitian ini kemudian datang dengan ide untuk menguji performa situs covid19. kaltimprov.go.id berdasarkan kriteria-kriteria teknis yang terdapat dalam studi-studi sebelumnya.

Pada penelitian kali ini digunakan perangkat lunak/software bernama SortSite 5.3.5 yang berfungsi sebagai alat penguji otomatis berbasis daring. Adapun hal-hal yang diuji adalah Errors, Accessibility, Compatibility dan Standards yang juga disebut sebagai variabel. Pada variabel errors yang dilihat adalah sisi kualitas terutama broken links dan server configuration problems. Variabel berikutnya adalah accessibility yang 
melihat isu terkait akses situs web untuk orang-orang tertentu seperti orang usia lanjut, orang dengan disabilitas dan orang dengan isu aksesibiltas tertentu. Variabel selanjutnya adalah compatibility yang melihat performa situs web yang diakses melalui berbagai browser dan system operasi. Variabel terakhir adalah standards yang melihat kepatuhan halaman situs web dengan standar yang ditetapkan oleh W3C.

Berdasarkan hasil evaluasi yang didapatkan dari aplikasi SortSite 5.3.5 didapatkan data bahwa masalah terbanyak pada situs web covid19.kaltimprov.go.id berada pada variabel accessibility dengan $85 \%$, kemudian variabel compatibility dan standards dengan rata-rata $72 \%$ dan yang terakhir adalah variabel errors dengan rata-rata permasalahan sebesar $71 \%$. Tentu saja hal ini merupakan temuan yang mengkhawatirkan dikarenakan banyaknya permasalahan secara teknis yang terdapat dalam situs web covid19.kaltimprov.go.id.

Meski begitu, khusus untuk variabel errors, hasil evaluasi SortSite 5.3.5 tidak bisa dijadikan satu-satunya panduan untuk menilai kualitas situs web covid19. kaltimprov.go.id, khususnya pada aspek spelling errors karena pada dasarnya SortSite dikembangkan dengan basis default Bahasa Inggris. Untuk itu, sebagai bahan pertimbangan bagi penelitian selanjutnya, perlu dipertimbangkan kerangka evaluasi situs web pada aspek spelling errors yang bisa mengakomodasi bahasa selain Bahasa Inggris, misalnya dalam konteks kali ini, Bahasa Indonesia.

Dengan demikian perlu bagi Pemerintah Provinsi Kalimantan Timur untuk lebih memperharikan dimensi teknis yang terkandung dalam situs covid19.kaltimprov. go.id. Dimensi teknis yang terdiri dari variabel evaluasi yang ditentukan oleh SortSite merupakan kriteria dalam membangun website yang lebih baik. Untuk itu Pemerintah Provinsi Kalimantan Timur perlu untuk melibatkan ahli dalam bidang IT development guna menyiapkan hal-hal yang terkait dengan pembentukan situs web. Selain itu perlu juga untuk memperhatikan aspek demografi, geografi, infrastruktur dan kondisi sosial penduduk Kaltim yang tentu saja memiliki perbedaan antara penduduk urban dan rural. Hal ini tidak lain karena situs web covid19. kaltimprov.go.id sudah selayaknnya menjadi rujukan utama bagi masyarakat Kaltim dalam mencari rujukan informasi yang benar dan valid terkait pandemi yang terjadi. Untuk itu permasalahan aksesibilitas dan kompatibilitas situs serta tampilan konten yang terdapat didalamnya harus benarbenar mudah untuk digunakan.

\section{Ucapan Terima Kasih}

Penulis mengucapkan terimakasih kepada pihak-pihak yang telah membantu penyelesaian artikel penelitian ini terutama kepada Koordinator Program studi Magister Administrasi Publik Fakultas Ilmu Sosial dan Ilmu Politik Universitas Mulawarman.

\section{Daftar Referensi}

Alismail, S., \& Chipidza, W. (2021). Accessibility evaluation of COVID-19 vaccine registration websites across the United States. Journal of the American Medical Informatics Association, 28(9), 1990-1995. https://doi.org/10.1093/JAMIA/OCAB105

Aminah, S., Sipahutar, H., Hs, T., Apriani, T., \& Maemunah, S. (2021). The Barriers of Policy Implementation of Handling Covid-19 Pandemic in Indonesia. 08(01), 1222-1241. https://ejmcm.com/ article_6798_1b62967de65b0c73a21d0ddeea9002bf.pdf

Cahyono, T. A., \& Susanto, T. D. (2019). Acceptance factors and user design of mobile e-government website (Study case e-government website in Indonesia). Procedia Computer Science, 161, 90-98. https://doi. org/10.1016/j.procs.2019.11.103

CNBC Indonesia. (2021). Kabar Terbaru: 5 Daerah RI yang Jadi Episentrum Covid-19. Retrieved from https://www.cnbcindonesia.com/news/20210825204804-4-271293/kabar-terbaru-5-daerah-riyang-jadi-episentrum-covid-19

Djuyandi, Y., Herdiansah, A. G., Yulita, I. N., \& Sudirman, S. (2019). Using vote E-recapitulation as a means to anticipate public disorders in election security in Indonesia. Humanities and Social Sciences Reviews, 7(5), 111-122. https://doi.org/10.18510/hssr.2019.7515

Effendi, P. M., \& Susanto, T. D. (2019). Test of citizens' physical and cognitive on Indonesian e-government website design. Procedia Computer Science, 161, 333-340. https://doi.org/10.1016/j. procs.2019.11.131

Elling, S., Lentz, L., de Jong, M., \& van den Bergh, H. (2012). Measuring the quality of governmental websites in a controlled versus an online setting with the "Website Evaluation Questionnaire." Government Information Quarterly, 29(3), 383-393. https://doi.org/10.1016/j.giq.2011.11.004

Fithriyaningrum, D., Kusumawardhani, S. S., \& Wibirama, S. (2021). Analisis Aksesibilitas Website 
berdasarkan Web Content Accessibility Guidelines (WCAG): Ulasan Literatur Sistematis. Jurnal IPTEKKOM, 23(1), 79-92. https://jurnal.kominfo.go.id/index.php/iptekkom/article/view/3473/1546

Hermansyah, Jumroh, \& Djuyandi, Y. (2019). Does the E-Procurement Eradicate the Corruption ? International Journal of Advanced Science and Technology, 28(14), 476-482. https://www. researchgate.net/ publication/338221138_Does_the_E-Procurement_Eradicate_the_Corruption_A_Lesson_from_EProcurement_Practices_in_Indonesia

Holzer, M., \& Manoharan, A. P. (2016). Digital Governance in Municipalities Worldwide (2015-16) Seventh Global E-Governance Survey: A Longitudinal Assessment of Municipal Websites Throughout the World. In Governance An International Journal Of Policy And Administration. New Jersey: National Center for Public Performance. https://www.seoulsolution.kr/sites/default/files/gettoknowus/Rutgers\%20SPAA Digital\%20Governance\%20in\%20Municipalities\%20Worldwide\%20\%282015-16\%29.pdf

Ikhsani, E. S., \& Rifki, M. S. (2017). Inovasi Tata Kelola Izin Mendirikan Bangunan di Kota Pontianak. Matra Pembaruan, 1(3), 143-152. https://doi.org/10.21787/mp.1.3.2017.143-152

Irawan, B., \& Hidayat, M. N. (2019). Evaluating Local Government' Website Using a Synthetic Website Evaluation Model. Samarinda.

Irawan, B., Hidayat, M. N., Akbar, P., \& Khanz, A. H. (2020). Inovasi Pelayanan Permohonan Pengajuan Izin Dinas Penanaman Modal dan Pelayanan Terpadu Satu Pintu (DPMPTSP) Kota Samarinda. Matra Pembaruan, 4(2), 135-145. https://doi.org/10.21787/mp.4.2.2020.135-145

Jesica, C. N., Sumadinata, R. W. S., \& Paskarina, C. (2020). Effects of Mass Media and Digital Media Internet on Young Voter Participation. JPPUMA Jurnal Ilmu Pemerintahan Dan Sosial Politik Universitas Medan Area, 8(1), 57-67. https://doi.org/10.31289/jppuma.v8i1.3393

Karkin, N., \& Janssen, M. (2014). Evaluating websites from a public value perspective: A review of Turkish local government websites. International Journal of Information Management, 34(3), 351-363. https:// doi.org/10.1016/j.ijinfomgt.2013.11.004

Kesswani, N., \& Kumar, S. (2016). Accessibility analysis of websites of educational institutions. Perspectives in Science, 8, 210-212. https://doi.org/10.1016/j.pisc.2016.04.031

Khalid, S. A., \& Lavilles, R. Q. (2019). Maturity assessment of local E-government websites in the Philippines. Procedia Computer Science, 161, 99-106. https://doi.org/10.1016/j.procs.2019.11.104

Kondoro, A., \& Mtebe, J. (2017). Accessibility and Usability of Government Websites in Tanzania. The African Journal of Information Systems, 9(4), 262. Retrieved from http://196.44.162.10:8080/xmlui/ handle/20.500.11810/4573

Layne, K., \& Lee, J. (2001). Developing fully functional E-government: A four stage model. Government Information Quarterly, 18(2), 122-136. https://doi.org/10.1016/S0740-624X(01)00066-1

Lee-Geiller, S., \& Lee, T. (David). (2019). Using government websites to enhance democratic E-governance: A conceptual model for evaluation. Government Information Quarterly, 36(2), 208-225. https://doi. org/10.1016/i.giq.2019.01.003

Lee, T. D., Lee-Geiller, S., \& Lee, B. K. (2021). A validation of the modified democratic e-governance website evaluation model. Government Information Quarterly, 38(4), 101616. https://doi.org/10.1016/J. GIQ.2021.101616

Lee, V. J., Chiew, C. J., \& Khong, W. X. (2020). Interrupting transmission of COVID-19: Lessons from containment efforts in Singapore. Journal of Travel Medicine, 27(3), 1-5. https://doi.org/10.1093/JTM/ TAAA039

Moleong, L. J. (2017). Metodologi Penelitian Kualitatif (37th ed.). Bandung: PT. Remaja Rosdakarya. http:// inlislite.uin-suska.ac.id/opac/detail-opac?id=12221

Moon, M. J. (2002). The evolution of E-government among municipalities: Rhetoric or reality? Public Administration Review, 62(4), 424-433. https://doi.org/10.1111/0033-3352.00196

Paskarina, C. (2020). Digital Activism and Democracy in Indonesia: Learning from the Foregoing Research Issues (2014-2020). Indonesian Journal of Political Research, 1(December 2020). https://doi. org/10.22500/8202028955

Prahono, A., \& Elidjen. (2015). Evaluating the Role e-Government on Public Administration Reform: Case of Official City Government Websites in Indonesia. Procedia Computer Science, 59(Iccsci), 27-33. https:/f doi.org/10.1016/j.procs.2015.07.334

Prahono, A., \& Elidjen. (2017). Evaluating the Implementation of Public Information Disclosure on the Official Website of Indonesian Ministries. Procedia Computer Science, 116, 54-60. https://doi.org/10.1016/j. procs.2017.10.008

Ratna Sari, Y. (2019). Manajemen Retribusi Pasar Melalui Inovasi Tape Pasar di Kota Surakarta. Matra Pembaruan, 3(1), 13-23. https://doi.org/10.21787/mp.3.1.2019.13-23

Reis, A., Martins, P., Borges, J., Sousa, A., Rocha, T., \& Barroso, J. (2017). Supporting Accessibility in Higher Education Information Systems: A 2016 Update. Lecture Notes in Computer Science (Including Subseries Lecture Notes in Artificial Intelligence and Lecture Notes in Bioinformatics), 10277 LNCS, 227-237. https://doi.org/10.1007/978-3-319-58706-6_19

Sofianto, A. (2019). Inovasi Manajemen Pemerintahan Berbasis Aplikasi Digital di Provinsi Jawa Tengah. Matra Pembaruan, 3(2), 99-108. https://doi.org/10.21787/mp.3.2.2019.99-108

SortSite 5.3.5. (2020). SortSite 5.3.5 Evaluation on covid19.kaltimprov.go.id. Samarinda.

Tollefsen, M., \& Ausland, T. (2018). A practitioner's approach to using WCAG evaluation tools. 2017 6th International Conference on Information and Communication Technology and Accessbility, ICTA 2017, 2017-December, 1-5. https://doi.org/10.1109/ICTA.2017.8336047

W3C. (2008). Web Content Accessibility Guidelines (WCAG) 2.0. Retrieved October 25, 2020, from 2008 website: https://www.w3.org/TR/WCAG20/

Yerlikaya, Z., \& Durdu, P. O. (2017). Evaluation of accessibility of university websites: A case from turkey. Communications in Computer and Information Science, 714, 663-668. https://doi.org/10.1007/9783-319-58753-0_94 